\title{
PERANAN SISTEM PENGENDALIAN INTERNAL TERHADAP EFEKTIVITAS PENGADAAN BARANG PADA BALAI BESAR PASCAPANEN BOGOR
}

\author{
Tiara Timuriana \\ Dosen Tetap Fakultas Ekonomi \\ Universitas Pakuan \\ Hendrian Octaviandi \\ Mahasiswa Fakultas Ekonomi \\ Universitas Pakuan
}

\begin{abstract}
ABSTRAK
Pengadaan barang adalah salah satu cara organisasi pemerintah untk memenuhi kebutuhan sarana dan prasarana yang dapat mendukung kegiatan operasi organisasi pemerintah. Balai Besar Pascapanen sebagai salah satu organisasi pemerintah dibawah Kementrian Pertaniaan terus berupaya meningkatakan kualitas pelayanan public dengan meningkan sarana dan prasarana untuk mendukung kegiatan operasi organisasi melalui kegiatan pengadaan barang.

Penelitian ini dilakukan dengan metode kualitatif dan kuantitatif terhadap kuesioner pengendalian internal pengadaan barang yang mengacu pada kerangka kerja COSO pada komponen-komponen struktur pengendalian internal. Simpulannya bahwa kegiatan pengadaan barang di Balai Besar Pascapanen tidak dilakukan berdasarkan kebutuhan akan barang terutama dalam pengaadan peraltan laboratorium, struktur pengendalian internal yang kurang memadai karena kompenen-komponennya masih banyak memiliki kelemahan dan sistem pegendalian internal yang belum bisa mendorong terjadinya efektivitas pada kegiatan pengadaan di Balai Besar Pascapanen Bogor.
\end{abstract}

Kata kunci : lingkungan pengendalian, penaksiran resiko, ativita pengendalian, informasi dan komunikasi, pemantauan.

\section{Pendahuluan}

Organisasi sektor publik khususnya pemerintah merupakan organisasi yang mengunakan dana dari masarakat dalam menjalankan kegiatan operasinya dengan maksud untuk mencapai tujuan organisasi yang telah ditetapkan atau diamanatkan dalan UUD RI Tahun 1945 yang menyatakan "Negara berkewajiban melayani setiap warga Negara dan penduduk untuk memenuhi hak dan kebutuhan dasarnya".

Pada pasal 3 Keppres No. 80Tahun 2003 tentang pedoman Pelaksanaan Pengadaan Barang atau Jasa Pemerintah menyatakan bahwa kegiatan pengadaan barang atau jasa pemerintah wajib menerapkan prinsip-prinsip : efesiensi, efektif, atau pengadaan barang atau 
jasa dilakukan sesuat kebutuhan terbuka bagu penyedia jasa yang memenuhi persyaratan dan bersaing secara sehat, transparan dalam pelaksanaannya, adil dalam memilih calon penyelia barang atau jasa dan akuntabel yang berarti harus mencapai sasaran baik fisik, keuangan juga dapat memberikan manfaat bagi pemerintah maupun masyarakat.

Kegiatan pengaadan barang yang dulakukan Balai Besar Pascapanen dilakukan dengan dua cara, yaitu yang pertama dengan swakelola dan yang kedua melalui penyedia barang dan jasa. Kegiatan pengadaan barang pada Balai Besar Pascapanen dinilai kurang efektif karena setiap barang yang dibeli tidak mendukung kegiatan penelitian pertanian dalam rangka pengembangan produk-produk pertanian.

Adapun tujuan penelitian yang ingin dicapai adalah :

1. Untuk mengidentifikasi sistem pengadaan barang pada Balai Besar Pascapanen Bogor

2. Untuk mengidentifikasi struktur pengendalian internal pada Balai Besar Pascapanen Bogor apakah sudah memadai.

3. Untuk mengidentifikasi peranan sistem struktur pengendalian internal terhadap efektivitas pengadaan barang pada Balai Besar Pascapanen Bogor

\section{Metode Penelitian}

Dalam penelitian ini menggunakan metode analisis deskriptif kuatitatif dan kualiatatif nonstatistik, yaitu menggambarkan keadaan objek penelitian yang sebenarnya dan mengumpulkan data yang relevan yang tersedia kemudian disusun, dipelajari dan dianalisis lebih lanjut. Penelitian dilakukan tidak dengan alat analisis statistik namun menggunakan kerangka teoritis sebagai alat analisisnya.

\section{Hasil dan Pembahasan}

\subsection{Pengadaan Barang Di Balai Besar Pascapanen Bogor}

Pegadaan barang atau jasa di Balai Besar Pascapanen Bogor dilakukan untuk memenuhi kebutuhan akan barang atau jasa yang bisa mendukung kegiatan operasi Di Balai Besar Pascapanen itu sendiri. Pengadaan sendiri dibagai menjadi dua, yaitu pengadaan atas barang dan atas pengadaan jasa.

Pengadaan atas barang di Balai Besar Pascapanen meliputi : peralatan kantor, peralatan laboratorium dan kendaraan operasional. Sedangkan pengadaan atas jasa di Balai Besar Pascapanen meliputi : pemasangan instalasi listrik dan perawatan peralatan laboratorium, kendaraan operasional. 


\subsection{Sistem Pengadaan Barang Di Balai Besar Pascapanen Bogor}

Sistem pengadaan barang atau jasa di Balai Besar Pascapanen Bogor terdiri atas tiga komponen yaitu : keranga kerja hokum dan peraturan, penggunaan kode model dan manual prosedur. Dari ketiga komponen sistem pengadaan barang di Balai Besar Pascapanen, penulis akan membatasi pembahasan pada manual prosedut (standar prosedur pelaksaan) pengadaan barang saja. Hal ini dilakukan karena dua alasan yaitu :

1. Kerangka kerja hukum dan peraturan pengadaaan barang adalah keppres no 80 tahun 2013 yang merupakan aturan baku yang telah ditetapkan pemerintah mengenai pengadaan barang.

2. Penggunaan kode model dalam kegian pengadaan barang telah dilakukan oleh setiap orrganisasi pemerintah dengan tujuan untuk penyeragaman dan mengurangi inedsiensi dalam kegiatan tersebut.

\subsection{Struktur Pengendalian Internal}

Memadai atau tidaknya suatu struktur pengendalian internal di Balai Besar

Pascapanen tidak lepas dari komponene-komponen pengendalian internal yang memadai dan tidak mendikung tujuan atau fungsi pengendalian itu sendiri.

1. Lingkungan pengendalian internal yang berkaitan dengan sistem pengendalian internal pada kegiatan barang mencakup :Intergritas terhadap kompetensi, tidak adanya partisipasi dari Satua Pengawas Internal dari Kementrian Pertanian (Inspektoral Jendral), Kebijakan dan praktik yang umumnya berbeda.

2. Penaksiran resiko. Kurangnya efektifitasnya kegiatan pengadaan peralan leboratorium pada Balai Besar Pascapanen diakibatkan dari ketelambatan pencairan anggaran dai pemerintah akibat keterlambatan pengajuan anggaran.

3. Aktivitas pengendalian, mencakup : review terhadap aktivitas pengadaan barang di Balai Besar Pascapanen dinilai sudah cukup memadai karena ada tiga organisasi independen di luar Balai Besar Pascapanen, yaitu : Inspektoral Jendral (SPI), Badan Pemeriksa Keuangan (BPK) dan Kantor Pelayanan Pembendaharaan Negara (KPPN).

4. Informasi dan komunikasi. Informasi teradap kegiatan pengadaan barang dinilai telah efektif, hal ii ditandai dengan akses yang mudah dan cepat dalam memperoleh data aktivitas pengadaan barang dan menghubungi pihak-pihak yang berkaitan dengan kegiatan pengadaan barang di Balai Besar Pascapanen. Komunikasi atara atasan dan bawahan khususnya peneliti masih kurang efektif terkait degan kegiatan pengadaan perualatan laboratorium. 
5. Pemantauan. Pemantauan terhadap aktivitas pengadaan baran gsudah cukup memadai karena adanya pihak pengawasan intern yang ditunjuk oleh balai dan eksten yang berasal dari Inspektoral Jendral Kementerian Pertanian, Badan Pemeriksa Keuangan dan Kantor Pelayanan Pembendaharaan Negara.

\subsection{Efektivitas Pengadaan Barang}

Efektivitas suatu kegiatan pengaan peralatan laboratrium di Balai Besar Pascapanen dapat didorong oleh suatu sistem pengendalian internal yang memadai yang didalamnya terdiri dari struktur pengendalian internal dengan komponen-komponen pengendalian internal yang kuat. Kegiatan pengadaan barang atau jasa yang efektif di Balai Besar Pascapanen harus sesuai dengan pasa Keppres No. 80 Tahun 2003, yang dinyatakan bahwa pengaaan barang harus dilakukan bersasarkan prisnsip-prinsip sebagai berikut, yaitu : efisiensi, efektif, terbuka dan bersaing, transparan, adil atau tidak diskriminatif dan akuntabel.

\subsection{Evaluasi Terhadap Sistem Struktur Pengendalian Internal Terhadap Efektivitas Pengadaan Barang Di Balai Besar Pascapanen Bogor}

Efektivitas kegiatan pengadaan peralatan laboratorium tidak lepas dari peranan sistem pengendalian internal khususnya pada struktur pengendalian internal yang terkait dengan aktivitas pengadaan peralatan laboratorium di Balai Besar Pascapanen.

\section{Kesimpulan}

Berdasaran hasil analisis yang dilakukan mengenai Peranan Sistem Pengendalian Internal Terhadap Efektivitas Pengadaan Barang Pada Balai Besar Pascapanen Bogor, maka dapat disimpulkan :

1. Sistem pengadaan brang khusunya untuk peralatan laboratorium tidak berjalan sebgaimana mestinya. Hal ini ditandai dengan pengadaan peralatan laboratorium yang ilakukan tidak sesuai dengan kebutuhan para peneliti atau sesuai dengan prinsip dasari pengadaan barang yang tertuang dalam padal 3 Keppres No. 8 tahun 2003.

2. Struktur pengendalian internal yang ada di Balai Besar Pascapanen Bogor dinilai masih kurang memadai sehigga belum bisa mendorong terjadinya efektivitas pengadaan peralatan laboratorium. Kurang memadainya struktur pegendalian internal dalam kegiatan pegadaan peralatan laboratrium tidak lepas lemahnya komponen struktuk pengendalian internal yang ada didalamnya. 
3. Sistem pengendalian internal di Balai Besar Pascapanen belum bisa mendorong teradinya efektibitas kegiatan pengadaan peraltan laboratorium yang disebabkan karena pengadaan peralatan tidak dilaksanakan sesuai dengan pasal 3 Keppres No. 8 tahun 2003 tentang prinsip dasar pengadaan barang diorganisasi pemerintah menyakan bahwa "pengadaan barang/jasa harus sesuai dengan kebutuhan yang telah ditetapkan dan dapat memberikan manfaat sebesar-besarnya sesuai sasaran yang ditetapkan". Pengadaan peraltan laboratorium yang tidak sesuai kebutuhan berdampak pada penumpukan peralatan laboratorium digudang karena tidak bisa digunakan dan terhambatnya kegiatan penelitian di Balai Besar Pascapanen Bogor.

\section{Daftar Pustaka}

Amin Widjaja Tunggal. 2010. Principles of Internal Auditing. Harvarindo, Jakarta

Bapan Pemeriksa Keuangan Republik Indonesia. 2007. Standar Pemeriksa Keuangan egara $(S P K N)$. Bapan Pemeriksa Keuangan Republik Indonesia. Jakarta

Indra Bastian 2007. Audit Sektor Publik. Salemba Empat, Jakarta

Indra Bastian 2010. Akuntansi Sektor Publik: Suatu Pengantar. Erlangga, Jakarta

Sawyer, Dittenhofer, S Cheiner, 2005. Internal Auditing, Buku 1, Edisi 5, Salemba Empat, Jakarta

Tim Reality. 2008. Kamus Praktis Bahasa Indonesia. Edisi Pertama, reality Publisher. 